\title{
Epidemiological Study Of Risky Behaviours And Their Relation With Mental Ill Health Among Secondary School Students In Cairo
}

\author{
Essam A. El-Moselhy; Morsy A. Ammar; Khaled M. Abd-Allah; Ibrahim A. \\ Ismail* and Eman S. Abd-Allah** \\ Departments of Community Medicine, Psychiatry* and Community Health Nursing** \\ Faculty of Medicine and Nursing, Al-Azhar and Zagazig University
}

\begin{abstract}
A cross-sectional design was carried out on 827 students from general and technical secondary schools in Cairo. The aim of this study was to determine the prevalence of risky behaviours among the studied students, to assess their relation with sociodemographic factors and psychological problems and to explore student's attitude toward these behaviours. The data were collected by a standardized interviewing form. Different psychological symptoms were assessed using Middle Sex Hospital Questionnaire. The study showed, 54.1\% of the students were having unhealthy diet and tobacco smoking behaviours. Also, all the risky behaviours, except absence of physical exercise practice and suicide attempt, were more common among boys. The most important sociodemographic risk factors were; positive family history of risky behaviours, one parent family and the student's work beside studying $(\mathrm{OR}=7.11,4.07$ and 3.37, respectively). The most important reasons for unhealthy diet, carrying weapon and engagement in casual sex were imitation (55.2\%), to feel grown up (47.1\%) and peer pressure $(39.1 \%)$, respectively. While, the most common psychological problem was hysteria $(15.1 \%)$ and the most common neurotic trait was sadness (41.9\%). The most important psychological problems risk factors were obsession and hysteria $(\mathrm{OR}=5.53$ and 4.59 , respectively). While, the most important neurotic traits risk were irritability and sadness ( $\mathrm{OR}=9.53$ and 8.05 , respectively). No awareness to the reported risk was present among $96.4 \%$ of the students having the risky behaviours $(\mathrm{OR}=6.41)$.
\end{abstract}

\section{Introduction}

Adolescence is regarded as the time transition from childhood to adulthood. It is the period of intensified preparation for the coming role of adulthood and characterized by the dramatic physical changes of puberty and the complex emotional and social adjustments (Hamilton, 1998). Also, it is a period, which is associated with a prolonged and confused struggle to attain an independent adult status (El-Nouman et al., 1999). Egypt has today the largest cohort of adolescents in its history, more than 13 million boys and girls between age 10 to 19 according to the 1996 census (Ibrahim et al. 2000).

Recent advances in behavioural sciences have demonstrated, positive changes in life style contribute extensively to the betterment of physical and psychological well being as well as to the prevention of most risk factors which cause disability and diseases. So, investments which create a conductive environment for healthier behaviours are crucial to bring about the desired improvements in the health of nations (WHO, 2001).

Risk factors are experiences in adolescent's life that increase the chances of being victimized or developing one or more of behavioural problems. These problems include, unhealthy diet, inadequate physical activity, alcohol and other drug abuse, suicide, criminal behaviour(s) directed towards other persons or properties. The more risk factors are present, the greater the chances of behaviour problems to occur (Center For Research on Youth At Risk, 1997 and Kann et al., 2000). Risky behaviour is often regarded as normal in adolescents. Testing one's own capacities 
and experimenting with limits are seen as necessary factors in the process of establishing one's own identity (France, 2000). The health of adolescents is critically linked to the health related behaviours they chose to adopt. A limited number of behaviours contribute markedly to today's major killers. Among adolescents, the leading causes of death are closely linked to these behaviours (Kann et al., 2000). Because the great impact of injury on the health and well being of adolescents, the healthy people 2010 objectives encourage schools to provide a good comprehensive health education to prevent unintentional injury, violence and suicide (US Department of Health and Human Sources, 2000). Coordinated school health programs in conjunction with community efforts can prevent injuries among students and help them to establish lifelong safety skills (Kolbe, 1993 and Allensworth et al., 1997).

The annual prevalence of psychological problems in adolescents is not well documented. However, it is about $20 \%$, as the same in adults. In US, epidemiological studies revealed, $13.0 \%$ of adolescents aged up to 17 had anxiety (Report of The Surgeon General, 2001). Also, in Egypt, feeling of anxiety and fear represented the most common psychological problems among adolescents (Ibrahim et al., 2000).

The aim of the present study is to determine the prevalence of certain risky behaviours, to assess their relation with sociodemographic factors and psychological problems and to explore students' attitudes toward these behaviours among the secondary school students in Cairo.

\section{Subjects And Methods}

A cross-sectional, analytical, schoolbased study was carried out among secondary school students in Cairo, Egypt.

Three educational directorates were randomly selected; El-Waily, El-Zitoun and Helwan. Public secondary schools (general, technical and commercial) were enlisted. Two general secondary schools (one for girls and one for boys), two technical secondary schools (one for girls and one for boys) and two commercial secondary schools (for girls) were randomly selected (as there is no male commercial school). From each selected school, two classes were randomly chosen from the first and the second grades only (we did not include the $3^{\text {rd }}$ grade as they will not be convenient to the study relative to the other grades, as appeared from our pre-test work). While, from commercial secondary schools for girls, one class only was randomly selected from the first and the second grades. We preferred this selection, in case of commercial schools, in order to avoid increasing the number of the girls. So, four classes from each school were selected, except commercial schools; only two classes were selected. This selection gives 20 classes, which give 827 students, the total number of the studied sample. Out of them, there were 447 students with various types of risky behaviours. The rest of the students' (380) had no risky behaviours, and they represented the control group. The mean age of the students was 17.2 \pm 1.3 years.

An official permission from the Ministry of Education as well as an informed consent from the students to participate in the study was taken. The following tools were used:

First; a standardized interviewing form, adopting from the Center of Disease Control (1999) with some modifications, was used to collect the data (risky behaviours) from the participating students. The risky behaviours were unhealthy diet, absence of physical exercise, tobacco smoking, drugs and/or alcohol use, physical fight(s), carrying weapon, casual sex and suicide ideation and/or attempt. Unhealthy diet was determined by questions concerning with the diet quality (potato chips, soda,....etc) and quantity. Physical activity practice of the students was considered when the student participated in activities that cause sweating and hard breathing for $\geq 20$ minutes (Center of Disease Control, 1998). Tobacco smoking (cigarette and/or shisha) and drugs and/or alcohol use were categorized as irregulars and regulars. Irregulars were those students who have admitted to have ever tried or experimented 
tobacco (even one or two puffs) or drugs and/or alcohol (even one or two times). While, regulars were those students who have used tobacco and drugs and/or alcohol one or more days per week. Casual sex means any form of sexual contact with the other sex. The questionnaire was pre-tested and modified accordingly.

Second; a close ended precoded questionnaire included the sociodemographic characteristics, questions to screen for neurotic traits (irritability, insecurity feelings and sadness), questions to assess the hidden risk among students without the risky beahviours which include the following: questions assessing their awareness to the studied risky behaviours, questions to define the attitudes of the students without the risky behaviours towards their colleagues have these behaviours and questions to identify their reasons for why they did not practice these risky behaviours. On the other hand, this questionnaire includes questions to determine the reasons of practice these behaviours in case of the students have them. Similarly, this questionnnaire was pre-tested.

Third; Middle Sex Hospital Questionnaire was applied to all students. The questionnaire was divided into six subscales covering the following psychiatric symptoms, which are anxiety, phobia, obsession, somatization, depression and hysteria. The response to each item is scored 2,1 or 0 . A score of $\geq 9$ in any subscale indicate, the subject is suffering from psychiatric symptoms (Crown and Scrip, 1966; Crown et al., 1970 and Gawad et al., 1970).

Odds ratio (OR) with $95 \%$ confidence interval (CI), chi-square ( $\left.\chi^{2}\right)$ and MantelHaenszel $\chi^{2}$ were used as tests of significance. The significance level for $\chi^{2}$ and Mantel-Haenszel $\chi^{2}$ were accepted if the $\mathrm{P}$-value $\leq 0.05$.

\section{Results And Discussion}

In this study, (table 1) $54.1 \%$ of the students practised two or more of the risky behaviours; unhealthy diet and tobacco smoking. Regarding taking unhealthy diet, Reeves (2001) found, 77.2\% of Michigan adult residents didn't eat the recommended amount of fruits and vegetables. The difference in prevalence may be related to the difference in age as well as cultural differences between the two samples. While, Refaat (2002) reported prevalence $55.7 \%$ of her group of students had junk food. This result agreed with ours. With regard the risky behaviour of no physical activity practice $(47.3 \%)$. Adams et al. (1992) supported this finding and stated, although adolescents are more active than adults are, many adolescents do not engage in physical activity. In this regard, our study agrees with this observation. Refaat (2002) reported similar findings, $46.6 \%$ not practised physical activities. With regard tobacco smoking, $54.1 \%$ of our students were smokers, $25.2 \%$ regular smokers and $28.9 \%$ irregular smokers. New-Comb and Bentler (1988) stated, adolescents initiate tobacco smoking perceive themselves as taking acceptable risk as they smoke. ElMoghazi et al. (1991) and Khafagy (1996) reported, $14.6 \%$ prevalence of tobacco smoking among secondary school students in El-Sharkia and El-Mansoura, respectively. Khafagy (1996) noticed, 53.6\% of his group were irregular smokers. Also, ElNouman et al. (1999) reported, $13.0 \%$ of the first year university students were smokers and $46.8 \%$ have tried smoking. Dous (2001) reported $33.8 \%$ prevalence of smoking among students aged 13-15 years. The difference with our results may be related to the difference in the ages of the studied samples as the prevalence of smoking increases with increasing in age according to El-Moghazi et al. (1991) and Zhu (1992), however, regular smoking was close to our results, 20.0\%. Regarding drugs and/or alcohol use, these substances were used by $11.7 \%$ of the students $(7.4 \%$ and $4.3 \%$ were irregularly and regularly drugs and/or alcohol users). Our results were supported by Soueif et al. (1987, 1988 and 1990). They found, the prevalence of cannabis use was $5.05 \%, 8.79 \%$ and $11.44 \%$ for male secondary school and university students and industrial workers, respectively. El-Nouman et al. (1999) and Refaat (2001) reported prevalence of 9.3\% and $5.2 \%$, respectively for drug abuse. 
Also, Okasha et al. (1995) found, $42.0 \%$ of failed students were drug abusers. With regard violence behaviours namely, engagement in physical fight(s) and carrying weapon. Pratt and Greydanus (2000) stated, violence is a form of aggressive behaviour that has a debilitating effect on the optimal growth and development of youth. A marked rise in fear and frustration have been documented due to youth violence epidemic (Prothrow-Stith, 1995). So, regarding engagement in physical fight(s), $41.6 \%$ of students were engaged in physical fight(s), $27.6 \%$ one time, $7.5 \% \quad 2-5$ times and $6.5 \%$ six or more times. These results were higher than that of Kann et al. (2000) and Refaat (2001), as they reported $25.0 \%$ and $26.3 \%$ of their students were engaged in physical fights, respectively. These differences in prevalence might be attributed to the small age of our students with high attitude for violence. Regarding carrying weapon (table 1), $8.1 \%$ and $8.6 \%$ of students carried a weapon sometimes and mostly, respectively. These results were lower than results of Kann et al. (2000) and higher than results of Refaat (2001) as they reported $17.0 \%$ and $5.5 \%$ of their students carried weapon, respectively. Again, these differences in prevalence might be attributed to differrence in culture (Kann et al. 2000 ' study) or to sample characteristics (Refaat 2001' study). Fahmy and El-Safy (2003) reported, $15.3 \%$ of secondary school students in Zagazig had aggressive behaviour. With regard engagement in casual sex, $2.8 \%$ of students engaged in it. Gottlieb et al. (2002); Xu et al. (2002) and Dimitry-Abraham et al. (2003) supported our results, but they reported higher prevalence. Dimitry-Abraham et al. (2003) showed, 898 Mexican students aged 11 to 24 years, all of them initiated sexual activity. This high figure could be explained, much more sexual freedom in western countries. With regard suicide ideation and/or attempt, $5.6 \%$ of the students had suicide ideation and/or attempt. Garnefski and Diekstra (1995) stated, a great attention has paid to suicidal behaviour in youngsters of secondary schools in the form of one or more non-fatal suicide attempts. Moreover, Murphy (2000) stated, suicide is the third leading cause of death among youth aged 15-24 years. Center of Disease Control (1999) showed, $3 \%$ of high school students in the US, reported suicide attempts that required medical treatment. Also, El-Nouman et al. (1999) found, 3.7\% of the first year university students attempted suicide. While, Kann et al. (2000) and Refaat (2001) reported, $9.0 \%$ and $9.3 \%$ of American and Egyptian students, respectively had tried suicide. Our result came midway between these figures, $3 \% \& 3.7 \%$ and $9 \% \& 9.3 \%$.

With regard, distribution of risky behaviours among the studied students according to gender (table 2), we found, unhealthy diet consumption behaviour was more prevalent among boys than girls $(69.5 \%$ vs. $42.8 \%$, respectively) with a statistically significant difference. In this aspect, Refaat (2002) reported, $73.8 \%$ and $26.2 \%$ of males and females of her students, respectively practised unhealthy lifestyle, including unhealthy diet. Regarding the risky behaviour of no physical activity practice, $44.3 \%$ and $49.5 \%$ of the students were boys and girls, respectively, with no statistically significant difference. Refaat (2002) agreed with our results. Regarding tobacco smoking, $97.4 \%$ of the boys were smokers compared with $22.5 \%$ of the girls, with a statistically significant difference. El-Moghazi et al. (1991); Khafagy (1996); Bawazeer et al. (1999) and Hughes (2000) supported our results, they reported high prevalence of smoking among males compared with females. While, Felimban (1993) reported, $10.3 \%$ of female university students in Riyadh were smokers. On the other hand, Johnston et al. (2002) found, $4.9 \%$ of secondary school students were smokers. While, Sadek et al. (2002) found, $2.5 \%$ of female secondary school students were smokers. Regarding drugs and/or alcohol use, $25.6 \%$ of the boys and $1.7 \%$ of the girls were drug and/or alcohol users, with a statistically significant difference. These results were supported by the findings of Center of Disease Control (1998). Also, Sadek et al. (2002) reported, $3.9 \%, 15.9 \%$ and $0.7 \%$ of the students were drug, alcohol and cannabinoids users, 
respectively. The violence related behaviours; namely, engagement in physical fight(s) was found among 71.3\% of the boys and $20.0 \%$ of the girls, with a statistically significant difference. Also, carrying weapon behaviour was found among $35.6 \%$ of the boys and $2.9 \%$ of the girls, with a statistically significant difference. In the US, nearly $60 \%$ of adolescents reported at least one episode of dating violence (Avery-Leaf et al., 1997). Our results were supported by Center of Disease Control (1998) which reported, the males who engaged in physical fight and carried weapon represented $67.2 \%$ and $44.8 \%$, respectively, compared with $50.4 \%$ and $18.4 \%$ of the females, respectively. Refaat (2001) supported our results. Also, Fahmy and El-Safy (2003) reported, 14.9\% and $12.8 \%$ of their males and females students had aggressive behaviour, respectively. With regard, engagement in casual sex practice, $4.6 \%$ of the boys and $1.5 \%$ of the girls engaged, with a statistically significant difference. Gottlieb et al. (2002); $\mathrm{Xu}$ et al. (2002); Dimitry-Abraham et al. (2003) and El-Moselhy et al. (2004) supported our results, but they reported higher prevalence. El-Moselhy et al. (2004) observed, $12.2 \%$ of the males had casual sex, this high figure could be explained, higher age of their sample. Suicide ideation and/or attempt were practised by $2.0 \%$ of the boys and $8.1 \%$ of the girls, with a statistically significant difference. Hider (1998) stated, suicide attempt was more common among the females. Center of Disease Control (1998) showed, suicide attempt was practised by $20 \%$ of the females and $12.1 \%$ of the males. On the other hand, Paul et al. (2003) reported, 558 suicides were recorded among youth aged $15-24$ year; $83.9 \%$ were males and $16.1 \%$ were females.

With regard distribution of the studied and the control groups according to sociodemographic factors (table 3 ), it was reported that $55.7 \%$ of the studied group were $\geq 17$ years compared with $42.6 \%$ of the controls (OR=1.69, 95\% CI: 1.27-2.25). Khafagy (1996) reported, older students had more risk compared with youngers. SelnerO'Hagan et al. (1998) mentioned, young adolescent generally reported less exposure to violence than did old adolescent. Further, $48.3 \%$ of the studied group were males compared with $43.9 \%$ of the controls $(\mathrm{OR}=1.19$, 95\% CI: 0.90-1.58). Khafagy (1996) agreed, the male gender represented a risk factor for smoking $(\mathrm{OR}=5.9,95 \% \mathrm{CI}$ : 3.90-9.02). Fahmy et al. (1997) stated, male secondary school students had total scores of knowledge on drug use more than the females. Selner-O'Hagan et al. (1998) and Pratt \& Greydanus (2000) clarified, male adolescents generally reported more exposure to violence than did the females. At the same time, $19.2 \%$ of the studied group belong to one parent family compared with $5.5 \%$ of the control group $(\mathrm{OR}=4.07,95 \%$ CI: 2.41-6.93). In a further analysis, the results indicated, the mother as a head of the one parent family represented more risk relative to the father $(\mathrm{OR}=4.44$, 95\% CI: $2.47-8.10$, and $1.71,95 \%$ CI: $0.36-$ 10.63, respectively). This could be explained, one parent family had no powerful supervision on his/her son and/or daughter. Moreover, the mother as a head of one parent family had less powerful supervision. WHO (1998) stated, adolescents who are at high risk of developing behaviour problems usually have family disturbances such as a broken home or separation. Youssef et al. (1999) showed, family profile has direct association with violence behaviour of secondary school students. Fahmy et al. (1997) noticed, secondary school students lived in extended families had total scores of knowledge on drug dependence less than those lived in a nuclear family. Extended family might have powerful supervision on their son and/or daughter. Regarding birth order, $36.7 \%$ of the studied group were the first son or daughter compared with $33.2 \%$ of the controls (OR=1.17, 95\% CI: 0.87-1.57) and $43.6 \%$ of the studied group were the last son and/or daughter compared with $41.3 \%$ of the controls $(\mathrm{OR}=1.10$, 95\% CI: 0.83 1.46). El-Moghazi et al. (1991) and Khafagy (1996) showed, birth order more than the first was considered as a risk. While, Fahmy et al. (1997) found, the first and the last births had total scores of knowledge on drug use more than the 
middle birth order ones. With regard number of siblings, $16.1 \%$ of the studied group had neither brothers nor sisters compared with $14.7 \%$ of the controls (OR=1.11, 95\% CI: 0.75-1.65). Also, $44.5 \%$ of the studied group had $\geq 3$ either brothers or sisters compared with $41.3 \%$ of the controls $(\mathrm{OR}=1.14,95 \%$ CI: 0.86-1.52). El-Moghazi et al. (1991) and Khafagy (1996) supported our results. Khafagy (1996) showed, $\geq 3$ siblings represented a risk $(\mathrm{OR}=1.7,95 \% \mathrm{CI}: 1.24-2.22)$. On the other hand, Fahmy et al. (1997) reported, students live in a big sized family $(\geq 5)$ had total scores of knowledge on drug use less than those lived in a small sized family $(<5)$. Regarding work of the studied group, $23.0 \%$ of the studied group work compared with $8.2 \%$ of the controls $(\mathrm{OR}=3.37,95 \%$ CI:20.15-5.30). This was in accordance with Refaat (2001), who reported, 20.3\% and $35.1 \%$ of her studied sample had violence related behaviours and suicide attempts, respectively, were working beside studying. Moreover, $44.1 \%$ of the studied group, the educational level of their family head was less than preparatory compared with $41.3 \%$ of the controls $(\mathrm{OR}=1.12,95 \%$ CI: $0.84-1.49)$ and $40.9 \%$ of the studied group, the educational level of their family head was secondary compared with $36.1 \%$ of the controls $(\mathrm{OR}=1.23$, 95\% CI: 0.921.65). Khafagy (1996) showed, the educational level up to secondary was a risk factor. Also, $47.4 \%$ of the studied group, the occupation of their family head was unskilled labour compared with $39.7 \%$ of the controls (OR=1.37, 95\% CI: 1.03-1.82) and $37.6 \%$ of the studied group, the occupation of their family head was semiskilled and skilled labour compared with $37.6 \%$ of the controls $(\mathrm{OR}=1.00,95 \% \mathrm{CI}$ : 0.75-1.34). Also, Khafagy (1996) showed, labour occupation was a risk factor $(\mathrm{OR}=2.4,95 \%$ CI: 1.22-4.55). Collectively, $45.4 \%$ of the studied group, belong to low social class compared with $40.8 \%$ of the controls (OR=1.21, 95\% CI: 0.91-1.61) and $39.4 \%$ of the studied group, belong to middle social class compared with $36.6 \%$ of the controls (OR=1.13, 95\% CI: 0.84-1.51). Lastly, $85.5 \%$ and $45.3 \%$ of the studied and the control groups had various types of risky behaviours practices in their families, respectively (OR=7.11, 95\% CI: 5.0410.04). Warrburten et al. (1991); Khafagy (1996); El-Nouman et al. (1999) and Sadek et al. (2002) supported our results. Warrburten et al. (1991) stated, tobacco smoking, drug and alcohol use is vividly portrayed to adolescents as aspects of adulthood. Also, they suggested, adolescent's behaviour is greatly influenced by their family models. While, Khafagy (1996) reported, $52.8 \%$ and $63.5 \%$ of parents and siblings smoke in the student families, respectively $(\mathrm{OR}=2.0$ for each of them). Moreover, Jessor et al. (1998) reported, modeling by family members might keep adolescents away from sound behaviours practices.

With regard attitudes of the control group towards risky behaviours among the studied group (table 4), some positive attitudes were present. We found, 53.7\% and $50.8 \%$ of the control group, respectively, their attitudes were wish to help the risky behaviour students to quit suicide attempt and drug and/or alcohol using practices. Also, $62.4 \%, 47.9 \%$ and $33.7 \%$ of the control group, respectively, their attitudes were refusing casual sex, carrying weapon and suicide attempt practices among the studied sample. El-Nouman et al. (1999) supported our results, $64.5 \%$ and $73.8 \%$ offered to help drug users and suicide attempt, respectively. El-Nouman et al. (1999) stated, with proper guidance the constructive peer influence can be a force that is worthy of investment. Also, Jessor et al. (1998) showed, peer pressure might keep adolescents away from sound behaviours. While, $23.4 \%$ and $22.7 \%$ of the control group, respectively, expressed attitudes to find excuse for drug and/or alcohol use and no physical exercise practice among the studied sample. Also, $10.3 \%$ and $9.7 \%$ of the control group, respectively, their attitudes were showing sympathy for suicide attempt and smoking among the studied sample. Again, 80.8\%, $62.6 \%, 0.8 \%$ and $0.5 \%$ of the control group their attitudes were accepting unhealthy diet, absence of physical exercise, casual sex and suicide attempt among the studied group, respectively, El-Nouman et al. 
(1999) supported our results. These negative attitudes represent a hidden risk, as this group of the students could engage in practices one or more of the risky behaviours. So, this group of the students' necessities more detailed studies and focusing more attention and care to readjust their attitudes.

Regarding distribution of the control group according to their reasons for non practice of risky behaviours (table 5), health reserve was the main reason for healthy diet (79.5\%), physical exercise practice $(66.3 \%)$, no tobacco smoking $(55.8 \%)$ and no drug and/or alcohol use (53.2\%). While, social causes were the main reason for neither engagement in physical fight(s) nor carrying weapon $(63.7 \%$ and $59.2 \%$, respectively). Also, familial causes were the main reason for neither engagement in physical fight(s) nor carrying weapon $(20.3 \%$ for each of them). This was expected and accepted as $94.5 \%$ of the controls were belong to two parents family with powerful supervision. Our results were supported by WHO (1998) and Youssef et al. (1999). On the other hand, religion was the main reason for neither casual sex nor suicide attempt practices $(63.7 \%$ and $68.7 \%$, respectively). Felimban (1993) found, religion and health were the main reasons for no smoking (67.6\% and 58.3\%, respectively), among their university students. Furthermore, Bearman and Bruckner (2001); Abdullah et al. (2002) and ElMoselhy et al. (2004) showed, religion was a main factor in abstinence from casual sex.

With regard distribution of risky behaviours among the studied sample according to their reasons for practice (table 6 ), the most important reason for unhealthy diet behaviour was imitation (55.2\%), with a statistically significant difference. Warrburten et al. (1991) stated, adolescent's behaviour is greatly influenced by their family models. Also, Jessor et al. (1998) showed, modeling by family members keep adolescents near to risky behaviours practices. While, peer pressure was the most important reason for no physical exercise practice, smoking, drugs and/or alcohol use and engagement in casual sex $(34.8 \%, 32.0 \%, 32.0 \%$ and $39.1 \%$, respectively), with a statistically significant differences for all mentioned behaviours. Khafagy (1996); New-Comb and Bentler (1988); El-Nouman et al. (1999) and Sadek et al. (2002) supported our result regarding smoking. Also, Brook and Brook (1990); El-Nouman et al. (1999) and Sadek et al. (2002) supported our result regarding drug abuse. Brook and Brook (1990) stated, peer pressure might be a powerful influence on whether adolescent initiate using drugs or not. Howard et al. (1999) stated, low concordance between parents and adolescents was associated with perpetuation of violence. While, Amirkhmian et al. (2001) found, falling in love was the commonest reason (48.6\%) for sexual practice. At the same time desire to feel grown up was the most important reason for physical fight(s) and carrying weapon (29.7\% and $47.1 \%$, respectively); with a statistically significant differences. Lastly, loneliness feeling was the most important reason for suicide attempt $(84.8 \%)$, with a statistically significant difference.

With regard distribution of psychological symptoms, neurotic traits and awareness to the risk among the studied sample (table 7), $15.1 \%$ of the students had hysteria. Our result was close to the result reported by El-Nouman et al. (1999), $20.6 \%$. On the other hand, El-Lawindi and El-Salamony (2003) reported a low figure, $2.6 \%$. Regarding, obsession, $11.1 \%$ of the students had obsession. This result was lower than figures noticed by El-Nouman et al. (1999); Elkin (1999); Hammoda et al. (2000) and El-Lawindi \& El-Salamony (2003), as their figures were $20.6 \%, 27.6 \%$, $18.4 \%$ and $28.0 \%$, respectively. The difference between these figures and ours was, most probably, due to differences in the sociodemographic and sample setting characteristics for example, Hammoda et al. (2000) and El-Lawindi \& El-Salamony (2003)' studies. The subjects in these two studies were recruited from general secondary schools (did not include technical, compared to ours), included students from rural residence and the type of school was mixed. The relatively high figures of obsession mentioned above, including ours, might be due to the finding 
that obsessional symptoms were commonly endorsed in a general adolescent population (Hammoda et al., 2000). Depression was noticed among $8.7 \%$ of the students. Again, this result was lower than the figures which were reported by Davis and Craig (1998); El-Nouman et al. (1999) and El-Lawindi \& El-Salamony (2003), 10.0\%, $11.6 \%$ and $27.6 \%$, respectively. While, somatization was found among $8.5 \%$ of the students. This result was between the two figures reported by El-Lawindi \& El-Salamony (2003) and Elkin (1999), 2.6\% and 3.0\%, respectively and by El-Nouman et al. (1999), 12.0\%. Anxiety was observed among $6.2 \%$ of the students. This result was close to the figures which were noticed by Davis \& Craig (1998) and El-Nouman et al. (1999), $8.0 \%$ and $11.6 \%$, respectively. And lower than that showed by El-Lawindi and El-Salamony (2003), 32.3\%. Lastly, phobia, was found among $4.7 \%$. This result was close to the figure which was noticed by ElNouman et al. (1999), 7.6\% and lower than that showed by Elkin (1999) and ElLawindi \& El-Salamony (2003), $14.7 \%$ for each of both. This relatively low figure of phobia might be due to the nature of the technical secondary school students who didn't give the proper attention to their academic career. Moreover, neurotic traits were found in high percentages among these students; irritability (26.7\%), insecurity feelings (25.4\%) and sadness (41.9\%). These high figures, which reflect personality distresses could be expected, given the identity confusion accompanied this developmental period in human life cycle.

With regard distribution of the studied and the control groups according to the psychological symptoms, neurotic traits and awareness to the risk (table 8), $22.8 \%$ of the studied group had hysteria compared with $6.1 \%$ of the controls $(\mathrm{OR}=4.59,95 \% \mathrm{CI}$ : 2.79-7.61). While, $17.4 \%$ of the studied group had obsession compared with 3.7\% of the controls (OR=5.53, 95\% CI: 2.98$10.40)$. With regard somatization, $12.8 \%$ of the studied group had somatization symptoms, compared with $3.4 \%$ of the controls (OR=4.13, 95\% CI: 2.15-8.06). Regrding depression, $11.4 \%$ of the studied group had depression symptoms, compared with $5.5 \%$ of the controls $(\mathrm{OR}=2.20,95 \%$ CI: 1.26-3.86). With regrd anxiety, $8.7 \%$ of the studied group had anxiety symptoms, compared with $3.2 \%$ of the controls (OR=2.93, 95\% CI: 1.46-6.01). Regrding phobia, $6.9 \%$ of the studied group had phobic symptoms, compared with $2.1 \%$ of the controls (OR=3.47, 95\% CI: $1.50-8.28)$. With regard neurotic traits, $37.8 \%$ of the studied group were having insecurity, compared with $13.7 \%$ of the controls $(\mathrm{OR}=3.83$, 95\% CI: 2.67-5.52). Moreover, $41.2 \%$ of the studied group were irritable compared with $6.8 \%$ of the controls $(\mathrm{OR}=9.53$, 95\% CI: 6.01-15.18). Also, $62.9 \%$ of the studied group were sad compared with $17.4 \%$ of the controls $(\mathrm{OR}=8.05$, 95\% CI: 5.73-11.33). Lastly, $96.4 \%$ of the studied group had no awareness to the risk compared with $80.8 \%$ of the controls (OR=6.41, 95\% CI: 3.5511.69). Beautrais (2000) stated, the strongest risk factors for youth suicide are mental disorders and a history of psychopathology.

Regarding distribution of the risky behaviours among the studied sample according to the psychological symptoms, neurotic traits and awareness to the risk (table 9), 8.1\%, 52.8\% and $96.4 \%$ of unhealthy diet group had hysteria, sadness and no awareness to the risk respectively. Cotrufo et al. (2005) didn't find similar results, this might be due to more severe forms of eating disorders among their group as well as cultural differences between the two communities. Also, 10.0\%, 27.4\% and $83.6 \%$ of no physical exercise practice group had hysteria, sadness and no awareness to the risk, respectively. At the same time, $10.7 \%, 61.3 \%$ and $64.0 \%$ of smoking group had somatization, insecurity and no awareness to the risk, respectively. While, $35.1 \%, 28.9 \%$ and $63.9 \%$ of drug and/or alcohol use group had symptoms of depression, anxiety and hysteria, respectively. Khadiga et al. (2004) reported, $61.2 \%, 5.55 \%$ and $5.55 \%$ of their addicts in Jeddah, KSA had depression, anxiety and hysteria, respectively. The difference between these figures and ours was, most probably, due to difference in the sample characteristics, namely being addicts in 
Khadiga et al. (2004)' study, with a high comorbid psychopathology, especially depression. Also, 21.2\%, 82.3\%, 72.4\% and $50.3 \%$ of physical fight(s) group had hysteria, insecurity, no awareness to the risk and sadness, respectively. Furthermore, $23.9 \%, 53.6 \%, 74.6 \%$ and $37.7 \%$ of carrying weapon group had obsession, insecurity, no awareness to the risk and sadness, respectively. El-Nouman et al. (1999) found, $68.3 \%$ and $32 . \%$ of their group with violence had insecurity and no awareness to the risk, respectively. Refaat (2001) found, relation between violence behaviour and insecurity and sadness. Also, Ritkallio et al. (2005) found, relation between delinquent behaviour and depression. While, 65.2\%, 69.6\% and $100.0 \%$ of casual sex practice group had obsession, insecurity and no awareness to the risk, respectively. Bennett \& Bauman (2000) and Ramrakha et al. (2000) reported an association between mental ill health and risky sexual health behaviour. Lastly, $89.1 \%, 69.6 \%, 95.7 \%$ and $30.4 \%$ of suicide attempt group had depression, insecurity, irritability and no awareness to the risk, respectively. Beautrais (2000) stated, the strongest risk factors for youth suicide are mental disorders and a history of psychopathology. El-Nouman et al. (1999) found similar figures, $56.3 \%$ and $28.6 \%$ of their group with suicide attempt had insecurity and no awareness to the risk, respectively. Furthermore, $68.3 \%$ and $32 . \%$ of their group with violence had insecurity and no attention to the risk, respectively. Moreover, Refaat (2001) found, a signifycant relation between suicide attempt and depression, anxiety and hysteria, a significant relation between drug abuse and depression and anxiety and a significant relation between smoking and depression. Also, Woods et al. (1997) showed, suicide attempt, was related to depression and impulsive behaviours.

We can conclude that risky behaviours and mental health problems were found to be common among secondary school students. Most of the risky behaviours were more common among boys. The most important sociodemographic risk factors were positive family history of risky behaviours, one parent family and the student's work besides studying. The most important reasons for that risky behaviours practices were imitation, feel grown up and peer pressure. The most common mental health problem was hysteria, while the most common neurotic trait was sadness. The most important mental health problem risk factors were obsession and hysteria. While, the most important neurotic traits risk were irritability and sadness. No awareness to the reported risk was present among most of the students. The current study supported the findings of the previous studies done in this field. It highlights the necessity of exploring risky behaviour (s) among the school adolescents, especially with those having one or more of mental health problems. Moreover, health professionals, families, schools and community should develop the sensitivity when encountering a teenager with mental health problems, in order to consider other health risks and behaviours. Conversely, an inquiry regarding mental health could be beneficial for a teenager presented by risk-taking behaviour (s). That should be an integration in medical and nursing curriculums as well as school health programs. Also, coordination between Families, schools and community as a whole to provide psychological support and to promote sound behaviours should be developed. At the end, more epidemiological researches should be carried out on a relatively bigger sample, as well as, using a research diagnostic criteria to screen for psychiatric disorders, rather than psychological symptoms, among adolescents on a national level. To sum up, the need for coordinated health care for adolescents covering psychological, sexual and social aspects is perhaps the most important point that should be made. 
Table (1): Distribution of the risky behaviours among the studied sample.

\begin{tabular}{|l|c|c|}
\hline \multicolumn{1}{|c|}{ Risky behaviours } & $\mathrm{N}=827$ & $\%$ \\
\hline Unhealthy diet: & 447 & 54.1 \\
Yes & & \\
\hline No physical exercise practice: & 391 & 47.3 \\
Yes & & \\
\hline Tobacco smoking: & 447 & 54.1 \\
Yes: & 239 & 28.9 \\
Irregular & 208 & 25.2 \\
Regular & & \\
\hline Drugs and/or alcohol use: & 97 & 11.7 \\
Yes: & 61 & 7.4 \\
Irregular & 36 & 4.3 \\
Regular & & \\
\hline Engagement in physical fight(s): & 344 & 41.6 \\
Yes: & 228 & 27.6 \\
1 time & 62 & 7.5 \\
2-5 times & 54 & 6.5 \\
\hline 6 times & & \\
\hline Carrying weapon: & 138 & 16.7 \\
Yes: & 71 & 8.1 \\
Sometimes & & 8.6 \\
Mostly & 23 & 2.8 \\
\hline Engagement in casual sex: & & \\
Yes & 46 & 5.6 \\
\hline Suicide ideation and/or attempt: & & 54.1 \\
\hline Yes & & \\
\hline Total number of students with risky behaviours & \\
\hline
\end{tabular}

Table (2): Distribution of the risky behaviours among the studied sample according to gender.

\begin{tabular}{|l|c|c|c|c|c|c|}
\hline \multirow{2}{*}{\multicolumn{1}{|c|}{ Risky behaviours }} & \multicolumn{2}{c|}{ Boys } & \multicolumn{2}{c|}{ Girls } & \multirow{2}{*}{$\chi^{2}$} & \multirow{2}{*}{ P-value } \\
\cline { 2 - 6 } & $\mathrm{n}=348(42.1 \%)$ & $\mathrm{n}=479(57.9 \%)$ & & \\
\hline Unhealthy diet & 242 & 69.5 & 205 & 42.8 & 58.04 & 0.000 \\
\hline No physical exercise practice & 154 & 44.3 & 237 & 49.5 & 2.21 & 0.137 \\
\hline Tobacco smoking & 339 & 97.4 & 108 & 22.5 & 454.89 & 0.000 \\
\hline Drugs and/or alcohol use & 89 & 25.6 & 8 & 1.7 & 111.25 & 0.000 \\
\hline Engagment in physical fight(s) & 248 & 71.3 & 96 & 20.0 & 217.69 & 0.000 \\
\hline Carrying weapon & 124 & 35.6 & 14 & 2.9 & 155.12 & 0.000 \\
\hline Engagement in casual sex & 16 & 4.6 & 7 & 1.5 & 7.33 & 0.007 \\
\hline Suicide ideation and/or attempt & 7 & 2.0 & 39 & 8.1 & 14.42 & 0.000 \\
\hline
\end{tabular}


Table (3): Distribution of the studied and the control groups according to sociodemographic factors.

\begin{tabular}{|c|c|c|c|c|c|}
\hline \multirow{2}{*}{ Sociodemographic factors } & \multicolumn{2}{|c|}{$\begin{array}{c}\text { Studied group } \\
(\mathrm{n}=447)\end{array}$} & \multicolumn{2}{|c|}{$\begin{array}{c}\text { Control group } \\
(\mathrm{n}=380)\end{array}$} & \multirow{2}{*}{ OR $(95 \% \mathrm{CI})$} \\
\hline & No. & $\%$ & No. & $\%$ & \\
\hline $\begin{array}{l}\text { Age (years): } \\
\quad<17 \\
\quad \geq 17\end{array}$ & $\begin{array}{l}198 \\
249\end{array}$ & $\begin{array}{l}44.3 \\
55.7\end{array}$ & $\begin{array}{l}218 \\
162\end{array}$ & $\begin{array}{l}57.4 \\
42.6\end{array}$ & $\begin{array}{l}0.59(0.44-0.79) \\
1.69(1.27-2.25)\end{array}$ \\
\hline $\begin{array}{l}\text { Sex : } \\
\text { Male } \\
\text { Female }\end{array}$ & $\begin{array}{l}216 \\
231\end{array}$ & $\begin{array}{l}48.3 \\
51.7\end{array}$ & $\begin{array}{l}167 \\
213\end{array}$ & $\begin{array}{l}43.9 \\
56.1\end{array}$ & $\begin{array}{l}1.19(0.90-1.58) \\
0.84(0.63-1.11)\end{array}$ \\
\hline $\begin{array}{l}\text { Type of the family: } \\
\text { Two parents } \\
\text { One parent: } \\
\text { The mother } \\
\text { The father } \\
\text { Other relatives }\end{array}$ & $\begin{array}{c}361 \\
86 \\
73 \\
6 \\
7 \\
\end{array}$ & $\begin{array}{c}80.8 \\
19.2 \\
16.3 \\
1.3 \\
1.6\end{array}$ & $\begin{array}{l}359 \\
21 \\
16 \\
3 \\
2 \\
\end{array}$ & $\begin{array}{l}94.5 \\
5.5 \\
4.2 \\
0.8 \\
0.5\end{array}$ & $\begin{array}{r}0.25(0.14-0.41) \\
4.07(2.41-6.93) \\
4.44(2.47-8.10) \\
1.71(0.36-10.63)^{*} \\
3.01(0.57-29.80)^{*}\end{array}$ \\
\hline $\begin{array}{l}\text { Birth order: } \\
\quad \text { First } \\
\text { Middle } \\
\text { Last } \\
\end{array}$ & $\begin{array}{c}164 \\
88 \\
195\end{array}$ & $\begin{array}{l}36.7 \\
19.7 \\
43.6\end{array}$ & $\begin{array}{c}126 \\
97 \\
157\end{array}$ & $\begin{array}{l}33.2 \\
25.5 \\
41.3\end{array}$ & $\begin{array}{l}1.17(0.87-1.57) \\
0.72(0.51-1.01) \\
1.10(0.83-1.46)\end{array}$ \\
\hline $\begin{array}{l}\text { Numper of siblings: } \\
0 \\
1-2 \\
\geq 3 \\
\end{array}$ & $\begin{array}{c}72 \\
176 \\
199 \\
\end{array}$ & $\begin{array}{l}16.1 \\
39.4 \\
44.5\end{array}$ & $\begin{array}{c}56 \\
167 \\
157\end{array}$ & $\begin{array}{l}14.7 \\
44.0 \\
41.3 \\
\end{array}$ & $\begin{array}{l}1.11(0.75-1.65) \\
0.83(0.62-1.10) \\
1.14(0.86-1.52)\end{array}$ \\
\hline $\begin{array}{l}\text { Work with studying } \\
\text { Yes }\end{array}$ & 103 & 23.0 & 31 & 8.2 & $3.37(2.15-5.30)$ \\
\hline $\begin{array}{l}\text { Education of the family head: } \\
\leq \text { preparatory } \\
\text { Secondary } \\
\text { University }\end{array}$ & $\begin{array}{c}197 \\
183 \\
67\end{array}$ & $\begin{array}{l}44.1 \\
40.9 \\
15.0\end{array}$ & $\begin{array}{c}157 \\
137 \\
86\end{array}$ & $\begin{array}{l}41.3 \\
36.1 \\
22.6\end{array}$ & $\begin{array}{l}1.12(0.84-1.49) \\
1.23(0.92-1.65) \\
0.60(0.42-0.87)\end{array}$ \\
\hline $\begin{array}{l}\text { Occupation of the family head: } \\
\text { Unskilled labour } \\
\text { Semi-skilled/skilled } \\
\text { Professional }\end{array}$ & $\begin{array}{c}212 \\
168 \\
67\end{array}$ & $\begin{array}{l}47.4 \\
37.6 \\
15.0\end{array}$ & $\begin{array}{c}151 \\
143 \\
86 \\
\end{array}$ & $\begin{array}{l}39.7 \\
37.6 \\
22.6\end{array}$ & $\begin{array}{l}1.37(1.03-1.82) \\
1.00(0.75-1.34) \\
0.60(0.42-0.87)\end{array}$ \\
\hline $\begin{array}{l}\text { Social level: } \\
\quad \text { Low } \\
\text { Middle } \\
\text { High } \\
\end{array}$ & $\begin{array}{c}203 \\
176 \\
68 \\
\end{array}$ & $\begin{array}{l}45.4 \\
39.4 \\
15.2\end{array}$ & $\begin{array}{c}155 \\
139 \\
86 \\
\end{array}$ & $\begin{array}{l}40.8 \\
36.6 \\
22.6 \\
\end{array}$ & $\begin{array}{l}1.21(0.91-1.61) \\
1.13(0.84-1.51) \\
0.61(0.42-0.89) \\
\end{array}$ \\
\hline $\begin{array}{l}\text { Risky behaviour practice in family: } \\
\text { Yes }\end{array}$ & 382 & 85.5 & 172 & 45.3 & $7.11(5.04-10.04)$ \\
\hline
\end{tabular}

* Exact confidence limits

Table (4): Attitudes of the control group towards the risky behaviours among the students have them.

\begin{tabular}{|c|c|c|c|c|c|c|c|c|c|c|}
\hline \multirow{2}{*}{ Attitude } & $\begin{array}{l}\text { Unhea- } \\
\text { lthydiet }\end{array}$ & $\begin{array}{c}\text { No } \\
\text { exerc. }\end{array}$ & $\begin{array}{c}\text { Tobac.s } \\
\text { mok. }\end{array}$ & $\begin{array}{l}\text { Drug/ } \\
\text { alcohol }\end{array}$ & $\begin{array}{c}\text { Physic. } \\
\text { fight }\end{array}$ & $\begin{array}{l}\text { Carry. } \\
\text { weapan }\end{array}$ & $\begin{array}{c}\text { Casual } \\
\text { sex }\end{array}$ & $\begin{array}{l}\text { Suicide } \\
\text { attempt }\end{array}$ & \multirow[t]{2}{*}{$\chi^{2}$} & \multirow[t]{2}{*}{$\mathrm{P}$} \\
\hline & $\%$ & $\%$ & $\%$ & $\%$ & $\%$ & $\%$ & $\%$ & $\%$ & & \\
\hline Wish to quit & 6.1 & 3.9 & 48.2 & 50.8 & 34.7 & 22.1 & 27.9 & 53.7 & 126.00 & 0.00 \\
\hline Find excuse & 4.2 & 22.7 & 22.1 & 23.4 & 15.0 & 10.0 & 6.8 & 1.8 & 44.39 & 0.00 \\
\hline Sympathy & 1.8 & 2.4 & 9.7 & 6.1 & 8.7 & 6.3 & 2.1 & 10.3 & 15.41 & 0.03 \\
\hline Accept & 80.8 & 62.6 & 7.1 & 5.8 & 13.7 & 13.7 & 0.8 & 0.5 & 370.60 & 0.00 \\
\hline Refuse & 7.1 & 8.4 & 12.9 & 13.9 & 27.9 & 47.9 & 62.4 & 33.7 & 145.2 & 0.00 \\
\hline
\end{tabular}


Table (5): Distribution of the control group according to their reasons for non practice of the risky behaviours.

\begin{tabular}{|l|c|c|c|c|c|c|c|}
\hline \multirow{2}{*}{ Risky behaviours } & $\begin{array}{c}\text { Relig- } \\
\text { ious }\end{array}$ & Health & $\begin{array}{c}\text { Fam- } \\
\text { ilial }\end{array}$ & Social & Other & \multirow{2}{*}{$\chi^{2}$} & \multirow{2}{*}{ P-value } \\
\cline { 2 - 7 } & $\%$ & $\%$ & $\%$ & $\%$ & $\%$ & & \\
\hline Unhealthy diet & 0.5 & 79.5 & 11.1 & 1.3 & 7.6 & 282.07 & 0.00 \\
\hline No physical exercise & 2.4 & 66.3 & 17.1 & 7.1 & 7.1 & 175.50 & 0.00 \\
\hline Tobacco smoking & 7.6 & 55.8 & 20.3 & 12.1 & 4.2 & 110.00 & 0.00 \\
\hline Drugs/alcohol use & 20.5 & 53.2 & 7.6 & 16.3 & 2.4 & 98.38 & 0.00 \\
\hline Physical fight(s) & 5.0 & 3.2 & 11.3 & 63.7 & 16.8 & 158.75 & 0.00 \\
\hline Carrying weapon & 2.9 & 1.3 & 20.3 & 59.2 & 16.3 & 137.71 & 0.00 \\
\hline Casual sex & 63.7 & 7.1 & 17.1 & 8.4 & 3.7 & 157.13 & 0.00 \\
\hline Suicide attempt & 68.7 & 7.4 & 16.3 & 4.2 & 3.4 & 197.16 & 0.00 \\
\hline
\end{tabular}

Table (6): Distribution of the students have risky behaviours according to their reasons for practice.

\begin{tabular}{|l|c|c|c|c|c|c|c|c|}
\hline \multirow{2}{*}{ Risky behaviours } & $\begin{array}{c}\text { Curio- } \\
\text { sity }\end{array}$ & $\begin{array}{c}\text { Peer } \\
\text { press. }\end{array}$ & $\begin{array}{c}\text { Feel } \\
\text { grown }\end{array}$ & $\begin{array}{c}\text { Imita- } \\
\text { tion }\end{array}$ & $\begin{array}{c}\text { Lonel- } \\
\text { iness }\end{array}$ & Other & \multirow{2}{*}{$\chi^{2}$} & \multirow{2}{*}{ P-value } \\
\cline { 2 - 8 } & $\%$ & $\%$ & $\%$ & $\%$ & $\%$ & $\%$ & & \\
\hline Unhealthy diet & 8.3 & 31.8 & 2.0 & 55.2 & 1.6 & 1.1 & 795.63 & 0.00 \\
\hline No physical exercise & 0.0 & 34.8 & 10.7 & 33.0 & 5.4 & 16.1 & 291.51 & 0.00 \\
\hline Tobacco smoking & 6.5 & 32.0 & 29.5 & 26.0 & 2.9 & 3.1 & 309.80 & 0.00 \\
\hline Drugs/alcohol use & 4.1 & 32.0 & 27.8 & 24.7 & 8.3 & 3.1 & 58.40 & 0.00 \\
\hline Physical fight(s) & 13.7 & 25.3 & 29.7 & 27.0 & 2.6 & 1.7 & 193.09 & 0.00 \\
\hline Carrying weapon & 2.2 & 12.3 & 47.1 & 29.7 & 1.5 & 7.2 & 163.51 & 0.00 \\
\hline Casual sex & 13.0 & 39.1 & 21.7 & 17.4 & 4.4 & 4.4 & 14.03 & 0.02 \\
\hline Suicide attempt & 0.0 & 0.0 & 0.0 & 0.0 & 84.8 & 15.2 & 190.54 & 0.00 \\
\hline
\end{tabular}

Table(7): Distribution of the psychological symptoms, neurotic traits and awareness to the risk among the studied sample.

\begin{tabular}{|l|c|c|}
\hline \multicolumn{1}{|c|}{ Variables } & $\mathrm{N}=827$ & $\%$ \\
\hline Psychological symptoms: & & \\
Hysteria & 125 & 15.1 \\
Obsession & 92 & 11.1 \\
Depression & 72 & 8.7 \\
Somatization & 70 & 8.5 \\
Anxiety & 51 & 6.2 \\
Phobia & 39 & 4.7 \\
\hline Neurotic traits: & & \\
Insecurity & 221 & 26.7 \\
Irritability & 210 & 25.4 \\
Sadness & 347 & 41.9 \\
\hline Total number of students with psychological symptoms & 376 & 45.5 \\
\hline Awareness to the risk: & & \\
No awareness & 738 & 89.2 \\
\hline
\end{tabular}


Table (8): Distribution of the studied and the control groups according to the psychological symptoms, neurotic traits and awarness to the risk.

\begin{tabular}{|c|c|c|c|c|c|}
\hline \multirow[t]{2}{*}{ Variables } & \multicolumn{2}{|c|}{$\begin{array}{c}\text { Studied group } \\
(\mathrm{n}=447)\end{array}$} & \multicolumn{2}{|c|}{$\begin{array}{c}\text { Control group } \\
(\mathrm{n}=380)\end{array}$} & \multirow{2}{*}{ OR $(95 \% \mathrm{CI})$} \\
\hline & No. & $\%$ & No. & $\%$ & \\
\hline \multicolumn{6}{|c|}{ Psychological symptoms } \\
\hline Hysteria & 102 & 22.8 & 23 & 6.1 & $4.59(2.79-7.61)$ \\
\hline Obsession & 78 & 17.4 & 14 & 3.7 & $5.53(2.98-10.40)$ \\
\hline Somatization & 57 & 12.8 & 13 & 3.4 & $4.13(2.15-8.06)$ \\
\hline Depression & 51 & 11.4 & 21 & 5.5 & $2.20(1.26-3.86)$ \\
\hline Anxiety & 39 & 8.7 & 12 & 3.2 & $2.93(1.46-6.01)$ \\
\hline Phobia & 31 & 6.9 & 8 & 2.1 & $3.47(1.50-8.28)$ \\
\hline \multicolumn{6}{|c|}{ Neurotic traits } \\
\hline Insecurity & 169 & 37.8 & 52 & 13.7 & $3.83(2.67-5.52)$ \\
\hline Irritability & 184 & 41.2 & 26 & 6.8 & $9.53(6.01-15.18)$ \\
\hline Sadness & 281 & 62.9 & 66 & 17.4 & $8.05(5.73-11.33)$ \\
\hline \multicolumn{6}{|c|}{ Awareness to the risk } \\
\hline No awareness & 431 & 96.4 & 307 & 80.8 & $6.41(3.55-11.69)$ \\
\hline
\end{tabular}

Table (9): Distribution of the risky behaviours among the studied sample according to the psychological symptoms, neurotic traits and awareness to the risk.

\begin{tabular}{|l|c|c|c|c|c|c|c|c|}
\hline \multirow{2}{*}{ Variables } & $\begin{array}{c}\text { Unhea- } \\
\text { lthydiet } \\
\mathrm{n}=447\end{array}$ & $\begin{array}{c}\text { No } \\
\text { exerc. } \\
\mathrm{n}=391\end{array}$ & $\begin{array}{c}\text { Smok- } \\
\text { ing } \\
\mathrm{n}=447\end{array}$ & $\begin{array}{c}\text { Drug/ } \\
\text { alcohol. } \\
\mathrm{n}=97\end{array}$ & $\begin{array}{c}\text { Physic. } \\
\text { fight } \\
\mathrm{n}=344\end{array}$ & $\begin{array}{c}\text { Carry.w } \\
\text { eapon. } \\
\mathrm{n}=138\end{array}$ & $\begin{array}{c}\text { Casual } \\
\text { sex } \\
\mathrm{n}=23\end{array}$ & $\begin{array}{c}\text { Suicid } \\
\text { attempt } \\
\mathrm{n}=46\end{array}$ \\
\cline { 2 - 12 } & $\%$ & $\%$ & $\%$ & $\%$ & $\%$ & $\%$ & $\%$ & $\%$ \\
\hline \multicolumn{7}{|c|}{ Psychological symptoms } \\
\hline Hysteria & 8.1 & 10.0 & 9.2 & 63.9 & 21.2 & 20.3 & 26.1 & 58.7 \\
\hline Obsession & 1.8 & 2.3 & 5.4 & 27.8 & 10.5 & 23.9 & 65.2 & 39.1 \\
\hline Somatization & 2.5 & 4.1 & 10.7 & 37.1 & 9.3 & 21.0 & 26.1 & 10.9 \\
\hline Depression & 0.7 & 1.0 & 5.1 & 35.1 & 0.0 & 0.0 & 30.4 & 89.1 \\
\hline Anxiety & 3.8 & 6.6 & 6.9 & 28.9 & 7.6 & 21.0 & 26.1 & 17.4 \\
\hline Phobia & 2.7 & 2.3 & 4.7 & 7.2 & 1.7 & 2.9 & 21.7 & 28.3 \\
\hline \multicolumn{7}{|c|}{ Neurotic traits } \\
\hline Insecurity & 13.0 & 1.0 & 61.3 & 71.1 & 82.3 & 53.6 & 69.6 & 69.6 \\
\hline Irritability & 8.3 & 6.6 & 48.1 & 52.6 & 47.7 & 40.6 & 34.8 & 95.7 \\
\hline Sadness & 52.8 & 27.4 & 40.7 & 50.5 & 50.3 & 37.7 & 26.1 & 67.4 \\
\hline \multicolumn{7}{|c|}{ Awareness to the risk } \\
\hline No awareness & 96.4 & 83.6 & 64.0 & 69.1 & 72.4 & 74.6 & 100.0 & 30.4 \\
\hline
\end{tabular}

\section{References}

1. Abdullah AS, Fielding R, Hedley AJ and Luk YK (2002): Risk factors for sexually transmitted diseases and causal sex among
Chinese patients attending sexually transmitted disease clinics in Hong Kong. Sex Trans Dis, 29 (6): 360-5. 
2. Adams P, Schoenbern C, Mossa A and Kann L (1992): Healthy risk behaviours among our nation's youth: US, 1992. Departments of health and human services, public health service and vital and health statistics, 10 (192): 1520-95.

3. Allensworth D, Lawson E, Nicholson L and Wycho J (1997): Schools and health: Our nation's investment. National academy press, Washington.

4. Amirkhmian YA, Tunov DV and Kelly JA (2001): Risk factors for HIV and other sexually transmitted diseases among adolescents in $\mathrm{St}$ Petersburg, Russia. Fam Plan Perspect, 33 (3): 106-12.

5. Avery-Leaf $S$, Cascardi $M$ and O'Leary K. D (1997): Efficacy of a dating violence prevention program on attitudes justifying aggression. J Adolesc Health, 21: 11-7.

6. Bawazeer AA, Hattab AS and Mevales E (1999): First cigarette smoking experience among secondary school students in Aden, Republic of Yemen. In: Proceeding of the $13^{\text {th }}$, scientific session, Aden Faculty of Medicine.

7. Bearman PS and Bruckner $\mathbf{H}$ (2001): Promising the future virginity pledges and first intercourse. A J Sociology, 106: 859-912.

8. Beautrais AL (2000): Risk factors for suicide and attempted suicide among young people. Aust N Z J Psychiat, 34 (3): 420-36.

9. Bennett D and Bauman A (2000): Adolescent mental health and risky sexual behaviour. BMJ, 321: 2512.

10. Brook D And Brook J (1990): The etiology and consequences of adolescent drug use. In: Drug and alcohol abuse. Watson, M. (ed.), Hunmana Press, NJ, 330-62.

11. Center For Research on Youth At Risk (1997): The national crime prevention council report: Promoting positive outcomes in youth twelve to eighteen years of age.

12. Center of Disease Control (1996): Youth risk behaviour surveillance-
United States, 1995. MMWR, 45: 51-4.

13. Center of Disease Control (1998): Health risk behaviour of alternative high school students. Youth risk behaviour survey.

14. Center of Disease Control (1999): Youth risk behaviour surveillance. National altern-ative high school youth risk behaviour survey, United States, 1998. MMWR, 48 (55): 144.

15. Cotrufo P, Gnisci A and Coputo I (2005): Psychological characteristics of less severe forms of eating disorders: An epidemiological study among 259 female adolescents. J Adolesc, 28 (1): 14750.

16. Crown S and Scrip A (1966): A short clinical diagnostic self-rating scale for psy-choneurotic patients. Br J Psych, 12: 917-23.

17. Crown S, Duncan KP and Howell A (1970): Quoted from " ElShinnawy HA (2001): A study of the impact of stress in chronic illness on children and their parents. M.D. thesis in Psychiatry, Faculty of Medicine, Cairo University.

18. Davis $\mathbf{T}$ and Craig $T$ (1998): $A B C$ of mental health. BMJ Book, 5-8.

19. Dimitry-Abraham C, Cande-Glez CJ, Cruz-Valdez A, SanchezZamorano L, HernandezMarquez $C$ and Lazcano-Ponce $E$ (2003): Sexual and demographic risk factors for herpes simplex virus type 2 according to schooling level among Mexican Youths. Sex Trans Dis, 30 (7): 549-55.

20. Dous NM (2001): Report on the results of the global youth tobacco survey in Egypt. The National comprehensive tobacco control program, MOHP, Egypt.

21. Elkin G (1999): Introduction to clinical psychiatry. Appleton \& Lange,113-21.

22. El-Lawindi MI and El-Salamony OK (2003): Mental health profile among a group of secondary school students in Damitta. Egypt J Comm Med, 21 (2): 5-17.

23. El-Moghazi MA, El-Badawy AA, El-Morsy EA and Wassif SM (1991): Pattern of smoking and 
some related factors among school students in Sarkia Governorate. Egypt J Comm Med, 9 (3): 113-24.

24. El-Moselhy EA, Ammar MA, Rizk M, Atallah RB, Hassan HM, Osman AM, Shatat MA and Salem AS (2004): Sexually transmitted diseases in adult males: Demographic and behavioural risk factors. Sc J Az Med Fac (Girls), 25 (2): 183-204.

25. El-Nouman A, El-Derwi D and Shaheen O (1999): Some Psychological and behavioural disturbances in late adolescence. Egypt J Comm Med, 17 (3): 1-12.

26. Fahmy EM, El-Gendy SD and Ssmy V (1997): Impact of health education on the knowledge of secondary school students about drug dependence. Egypt J Comm Med, 15 (1): 45-60.

27. Fahmy HH and El-Safy ER (2003): Impact of media violence on school children's health and aggressive behaviour in Zagazig city. Egypt J Comm Med, 21 (2): 19-32.

28. Felimban FM (1993): The smoking practices and attitudes towards smoking of female university students in Riyadh. Saudi Med J, 14 (3): 220-4.

29. France A (2000): Towards a sociological understanding of youth and their risk taking. J Youth Studies, 3 (3): 317-31.

30. Garnefski N and Diekstra RR (1995): Suicidal behaviour and the co-occurrence of behavioural, emotional and cognitive problems among adolescents. Department of Clinical and Healthy Psychology, University of Leiden, Netherlands.

31. Gawad M, Gurgis $W$ and ElRakhawy Y (1970): Arabic version of Middle Sex Hospital Questionnaire. In: El-Shinnawy HA (2001): A study of the impact of stress in chronic illness on children and their parents. M.D. thesis in Psychiatry, Faculty of Medicine, Cairo University.

32. Gottlieb SL, Dauglas JM, Schmid DS, Bolan G, Iausta M, Malotte CK, Zenilman J, Foster M, Baron AE, Steiner JF, Peterman TA and Kamb ML (2002):
Seroprevalence and correlates of herpes simplex virus type 2 infection in five sexually transmitted disease clinics. J Infec Dis, 185: 1381-9.

33. Hamilton P (1998): Basic paediatric nursing. $8^{\text {th }}$ ed, Mosby Company, 127-34.

34. Hammoda MA, Ismail IA, AbdAl-fattah MS, Eisa AH, Mostafa AM and Hafez AS (2000): Point prevalence rates of obsessive compulsive symptoms and obsessive compulsive disorder in a sample of secondery school students in a rural area in Egypt. Current Psychiatry, 7 (2): 133-44.

35. Hider P (1998): Youth suicide prevention by primary health care professionals. Newzealand Health Technology Assessment, Report 4, Clearing House.

36. Howard DE, Cross SI, Li X And Huang W (1999): Parent-youth concordance regarding violence exposure: Relationship to youth psychological functioning. Adolesc Health, 25 (6): 396-406.

37. Hughes JH (2000) : Nicotine related disorders. In: Substance related disorders: A comprehensive textbook, Sadock BJ and Sadock VA (eds.), Williams and Willkins, Baltimore.

38. Ibrahim B, Sallam S, El-Gibaly O, El-Sahn $F$ and El-Tawila $S$ (2000): Transition to adulthood: A national survey of Egyptian adolescents. Population Council.

39. Jessor R, Turbin $M$ and Casta $F$ (1998): Protective factors in adolescent health behaviour. J Pers Soc Psychol, 75: 788-800.

40. Johnston LD, O'Malley PM and Bachman JG (2002): Monitor the future. National results on adolescent use, overview of key findings, 2001 US. Department of Health and Human Services, public health services, Natl Inst Health and Natl Inst Drug Abuse.

41. Kann L, Kinchen SA, Williams BI, Ross JG, Lowry $R$ and Grumbaum J (2000): Youth risk behaviour surveillance-US, 1999. J Sch Health, 7 (7): 271 - 85.

42. Khadiga AS, Abdul-Hafeez YK and Mohamed SG (2004): 
Demographic characteristics of addicts in Jeddah, KSA. Egypt $\mathbf{J}$ Comm Med, 22 (1): 29-38.

43. Khafagy MA (1996): Cigarette smoking among secondary school students in Mansoura Province, Egypt J Comm Med, 14 (1): 61-8.

44. Kolbe LJ (1993): An essential strategy to improve the health and education of Americans. Prev Med, 22: 544-60.

45. Murphy SL (2000): Deaths: Final data for 1998. Natl Vital Stat, 48: 1106.

46. New-Comb MD And Bentler FM (1988): Consequences of adolescents drug usage. Beverly Hills CA.

47. Okasha A, Kalil A, Fahmy M and Ghonem M (1995): Psychological understanding of Egyptian heroin users. Egypt J Psychiat, 13: 37-49.

48. Paul S, Brent $\mathbf{G}$ and Ruwan $\mathbf{R}$ (2003): Assessing suicidal youth with antisocial, borderline or Narcissistic disorder. Can J Psychiat, 48: 301-10.

49. Pratt HD and Greydanus DE (2000): Adolescent violence: Concepts for a new millennium. Adolesc Med, 11 (1): 103-25.

50. Prothrow-Stith D (1995): The epidemic of youth violence in America: Using public health prevention strategies to prevent violence. Health Care Poor Undeserved, 6 (2): 95-101.

51. Ramrakha S, Caspi A, Dickson N, Moffitt T and Paul C (2000): Psychiatric disorders and risky sex in young adulthood: A cross sectional study in a birth cohort. BMJ, 321: 263-6.

52. Refaat A (2001): Safety, violence and suicide: The unseen dangers among Egyptian University students. Egypt J Comm Med, 19 (3): 51-67.

53. Refaat A (2002): Healthy life style among university youth. Egypt J Comm Med, 20 (2): 49-57.

54. Reeves MJ (2001): Prevalence of healthy life style characteristicsMichigan, 1998 and 2000. MMWR, 50 (35): 758-61.

55. Report of The Surgeon General (2001): Mental health. Chapter 1,2: Introduction and epidemiology of mental illness. http:// www.surgeongeneral.gov/library/m entalhealth/sec3.html.

56. Ritkallio M, Kaltiala-Heino R, Kivivuori $J$ and Rinipela $R$ (2005): Brief report: Delinquent behaviour and depression in middle adolescence- A Finish community sample. J Adolesc, 28 (1): 155-9.

57. Sadek A, El-Mahllawy N, Haroun Elrashed A, El-Setouhy M, Soliman A and Zaki N (2002): Substance use disorders among female secondary school students in Cairo, Egypt. Egypt J Comm Med, 20 (4): 41-62.

58. Selner-O'Hagan MB，Kindlon DJ, Buka FJ Raudenbush SW and Earls FJ (1998): Assessing exposure to violence in urban youth. J Child Psychol Psychiatry, 39 (2): 215-24.

59. Soueif M, Hannourah MA, Darweesh ZA, El Sayed AM, Yunis F and Taha H (1987): The use of psychoactive substances by female university students compared with their male colleagues on selected items. Drug and Alcohol Depend, 19: 223-47.

60. Soueif M, Yunis F, Youssef G, Moneim H, Taha H, Sree $O$ and Badr K (1988): The use of psychoactive substances among the Egyptian males working in manufacturing industries. Drug and Alcohol Depend, 21: 217-34.

61. Soueif M, Youssef G, Taha H, Moneim H, Sree O, Badr K And Yunis F (1990): Use of psychoactive substances among male secondary school students in Egypt. Drug and Alcohol Depend, 26: 63-79.

62. US Department of Health and Human Services (2000): Healthy people 2010 (Conference, ed. 2, vol. 5), Washington.

63. Warrburten D, Revell AD and Thompson DH (1991): Smokers of the future. Br J Addict, 86: 621-5.

64. WHO (1998): Mental health promotion for school children. A manual for school teacher and school health workers. WHOEM/MNH/153/E/L.

65. WHO (2001): Promotion of healthy life style in the Eastern 
Mediterranean Region. Regional Committee for the Eastern Mediterranean, Saudi Arabia.

66. Woods ER, Lin YG, Middleman A, Beckford P, Chase $L$ and Rant RH (1997): The associations of suicide attempts in adolescent. Pediatrics, 99 (6): 791-6.

67. Xu F, Julia A, Schillinger M, Stermberg R, Johnson $F$ and Adve J (2002): Seroprevalence and co-infection with herpes simplex virus type I and type II in the U S, 1988-1999. J Infec Dis, 185 (8): 1019-24.

68. Youssef R, Attia $M$ and Kamel $M$ (1999): Violence among school children in Alexa-ndria. East Mediter Health J, 5: 282-98.

69. Zhu BP (1992): Cigarette smoking among junior high school students in Beijing, China J Epidemiol, 21 (5): 854-61.

\section{دراسة وبائية للسـوكيـات الخطرة و علاقتها باعتلا ل الصحة النفسية الخطرة لاي طلاب المدارس الثانوية بالقاهرة}

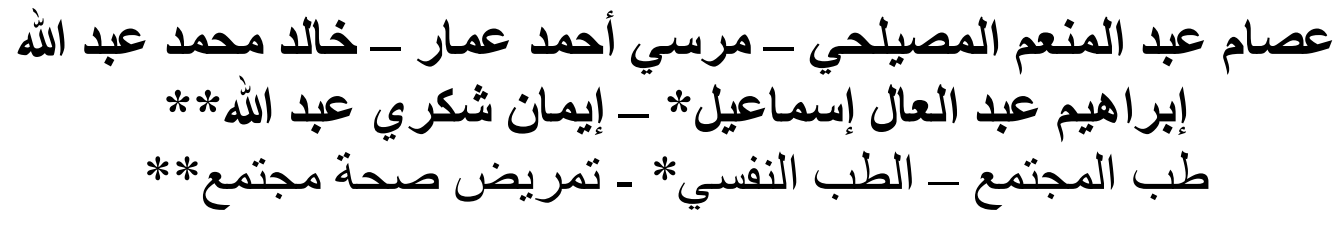

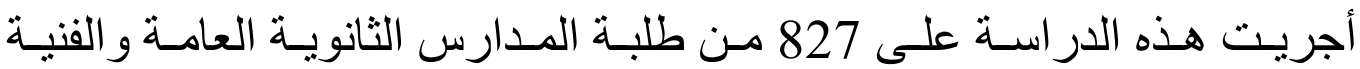

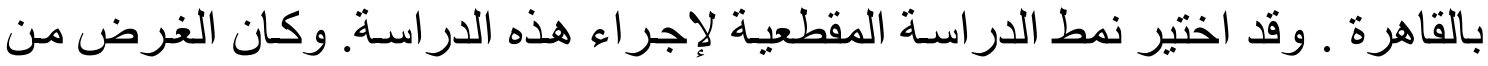




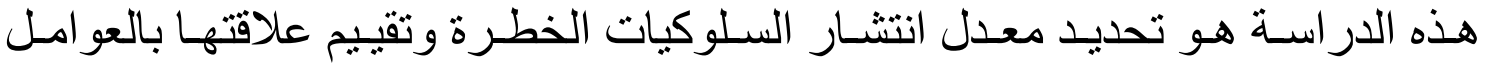

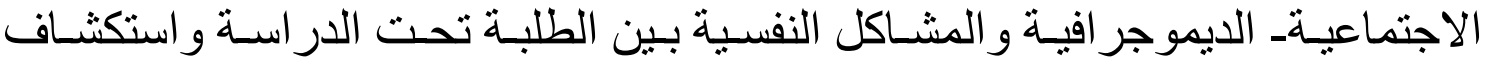
اتجاهات الطلبة بالنسبة لهذه السلوكيات. وقد تم جمع البيانات بو اسطة استبيان معياري

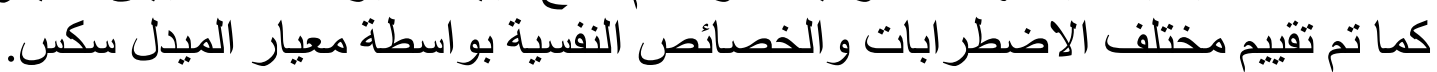

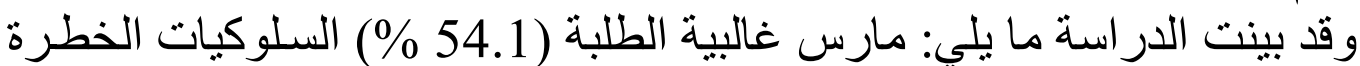

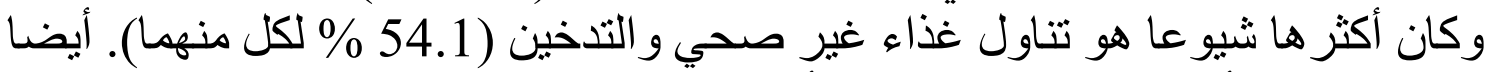

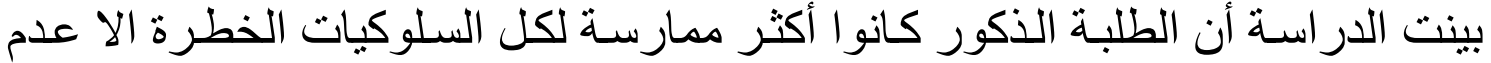

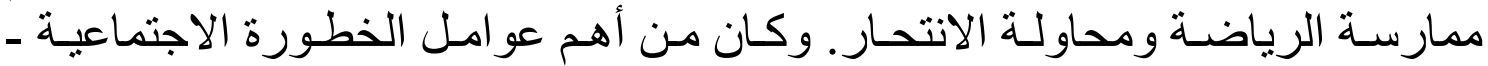

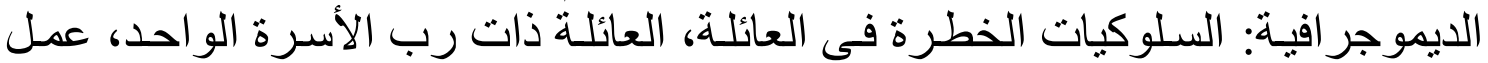

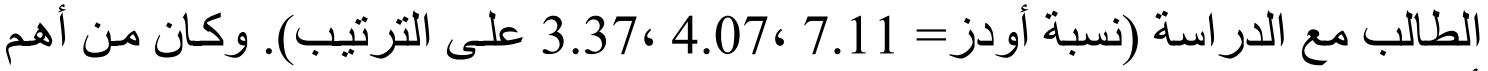

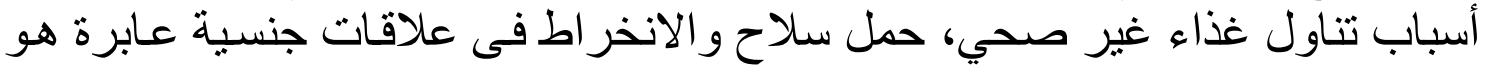

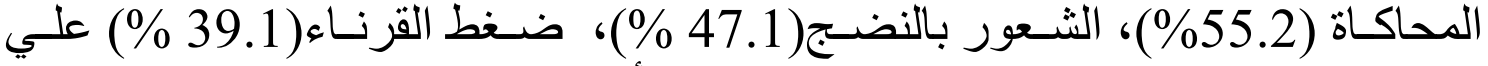

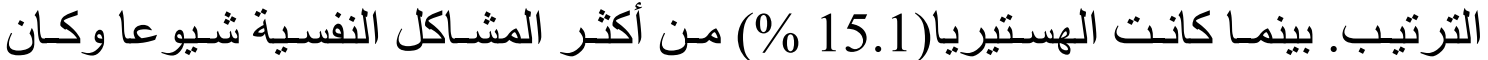

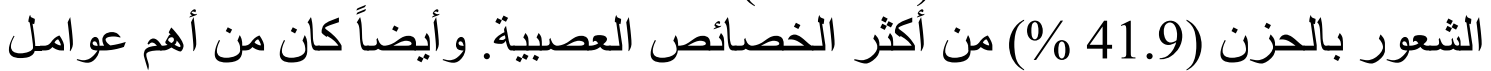

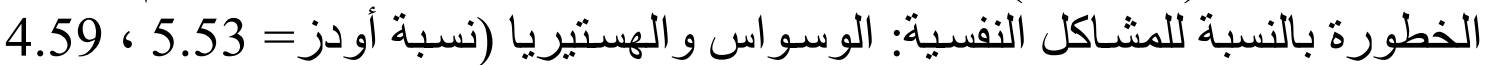

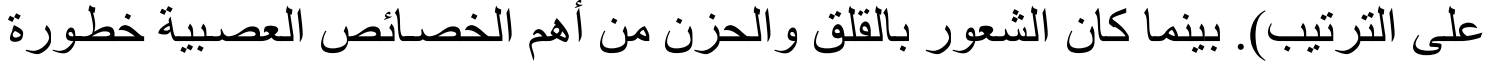

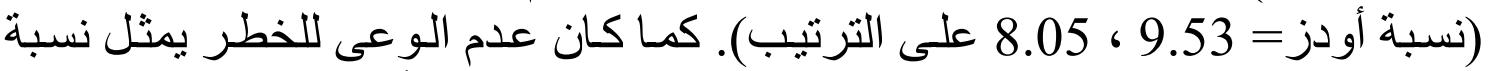

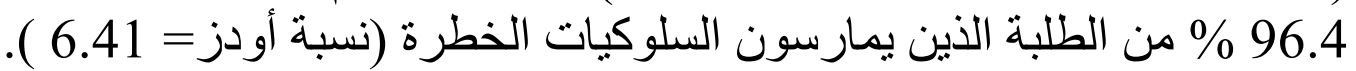

